\title{
Nonspecific stress response to temperature increase in Gammarus lacustris Sars with respect to oxygen-limited thermal tolerance concept
} \author{
Khomich $^{3}$, Daria Bedulina ${ }^{1}$, Egor Zadereev ${ }^{4,5}$, Maxim Timofeyev ${ }^{\text {Corresp. } 1}$ \\ 1 Institute of biology, Irkutsk State University, Irkutsk, Russia \\ 2 Baikal Research Centre, Irkutsk, Russia \\ 3 International Sakharov Environmental Institute, Belarusian State University, Minsk, Belarus \\ 4 Institute of Biophysics SB RAS, Krasnoyarsk Research Center SB RAS, Krasnoyarsk, Russia \\ 5 Siberian Federal University, Krasnoyarsk, Russia \\ Corresponding Author: Maxim Timofeyev \\ Email address: m.a.timofeyev@gmail.com
}

Kseniya Vereshchagina ${ }^{1,2}$, Elizaveta Kondrateva ${ }^{1}$, Denis Axenov-Gribanov ${ }^{1,2}$, Zhanna Shatilina ${ }^{1,2}$, Andrey

The previously undescribed dynamics of the heat shock protein HSP70 and subsequent lipid peroxidation products have been assessed alongside lactate dehydrogenase activity for Gammarus lacustris Sars, an amphipod species from the saltwater Lake Shira (Republic of Khakassia). Individuals were exposed to a gradual temperature increase of $1^{\circ} \mathrm{C} /$ hour (total exposure duration of 26 hours) starting from the mean annual temperature of their habitat $\left(7^{\circ} \mathrm{C}\right)$ up to $33^{\circ} \mathrm{C}$. A complex of biochemical reactions occurred when saltwater $\mathrm{G}$. lactustris was exposed to the gradual changes in temperature. This was characterized by a decrease in lactate dehydrogenase activity and the launching of lipid peroxidation. The HSP70 level did not change significantly during the entire experiment. In agreement with the concept of oxygen-limited thermal tolerance, an accumulation of the most toxic lipid peroxides (triene conjugates and Schiff bases) in phospholipids occurred at the same time and temperature as the accumulation of lactate. The main criterion overriding the temperature threshold was therefore the transition to anaerobiosis, confirmed by the elevated lactate levels as observed in our previous associated study, and by the development of cellular stress, which was expressed by an accumulation of lipid peroxidation products. An earlier hypothesis, based on freshwater individuals of the same species, has been confirmed whereby the increased thermotolerance of $G$. lacustris from the saltwater lake was caused by differences in energy metabolism and energy supply of nonspecific cellular stress-response mechanisms. With the development of global climate change, these reactions could be advantageous for saltwater G. lacustris. The studied biochemical reactions can be used as biomarkers for the stress status of aquatic organisms when their habitat temperature changes. 
1 Nonspecific stress response to temperature increase in Gammarus lacustris Sars with 2 respect to oxygen-limited thermal tolerance concept

3

4 Vereshchagina K.P. ${ }^{1,2}$, Kondrateva E.S. ${ }^{1}$, Axenov-Gribanov D.V., ${ }^{1,2}$ Shatilina Zh.M., ${ }^{1,2}$, 5 Khomich A.S. ${ }^{3}$, Bedulina D.S. ${ }^{1}$, Zadereev E. S. ${ }^{4,5}$, Timofeyev M.A. ${ }^{*}$

6

$7 \quad{ }^{1}$ Institute of biology, Irkutsk State University, Irkutsk, Russia

$8 \quad{ }^{2}$ Baikal Research Centre, Irkutsk, Russia

9 International Sakharov Environmental Institute, Belarusian State University, Minsk, Belarus

10 4Institute of Biophysics SB RAS, Krasnoyarsk Research Center SB RAS, Krasnoyarsk, Russia

$11{ }^{5}$ Siberian Federal University, Krasnoyarsk, Russia

12

13

$14 *$ Author for correspondence

15 Dr. Sci., Prof. Maxim A. Timofeyev

16 Irkutsk State University,

17 3-117 Lenin st.,

18 664025, Irkutsk, Russia

19 Tel: 7(9025)100893

20 Fax: 7(3952)243077

21 E-mail: m.a.timofeyev@gmail.com 
22

23

24

\section{Abstract}

The previously undescribed dynamics of the heat shock protein HSP70 and subsequent lipid peroxidation products have been assessed alongside lactate dehydrogenase activity for Gammarus lacustris Sars, an amphipod species from the saltwater Lake Shira (Republic of Khakassia). Individuals were exposed to a gradual temperature increase of $1{ }^{\circ} \mathrm{C} /$ hour (total exposure duration of 26 hours) starting from the mean annual temperature of their habitat $\left(7^{\circ} \mathrm{C}\right)$ up to $33{ }^{\circ} \mathrm{C}$. A complex of biochemical reactions occurred when saltwater G. lactustris was exposed to the gradual changes in temperature. This was characterized by a decrease in lactate dehydrogenase activity and the launching of lipid peroxidation. The HSP70 level did not change significantly during the entire experiment. In agreement with the concept of oxygen-limited thermal tolerance, an accumulation of the most toxic lipid peroxides (triene conjugates and Schiff bases) in phospholipids occurred at the same time and temperature as the accumulation of lactate. The main criterion overriding the temperature threshold was therefore the transition to anaerobiosis, confirmed by the elevated lactate levels as observed in our previous associated study, and by the development of cellular stress, which was expressed by an accumulation of lipid peroxidation products. An earlier hypothesis, based on freshwater individuals of the same species, has been confirmed whereby the increased thermotolerance of G. lacustris from the saltwater lake was caused by differences in energy metabolism and energy supply of nonspecific cellular stress-response mechanisms. With the development of global climate change, these reactions could be advantageous for saltwater G. lacustris. The studied biochemical reactions can be used as biomarkers for the stress status of aquatic organisms when their habitat temperature changes. 


\section{Introduction}

Temperature is one of the factors that determines functioning and stability of ecosystems. Temperature defines a number of processes in living organisms at all levels of organization (Iacarella, 2015; Huey, 2018). In recent years, surface temperature of lakes throughout the world has grown significantly (about $0.34{ }^{\circ} \mathrm{C}$ within 10 years) (O'Reilly et al., 2015; Yasuhara, Danovaro, 2016). Such rapid warming is a drastic signal for the need to study comprehensively the impact of climate change on the status of water ecosystems to assess the fauna vulnerability and adaptive capacity. In addition, this induces the need to develop new methods and tools for environmental protection. Studying thermal tolerance mechanisms and energy metabolism components in aquatic organisms in changing ambient temperature is of essential interest and relevance.

Recently to explain the ecological consequences of climate change, the concept of oxygen-and capacity-limited thermal tolerance (OCLTT) have been used (Pörtner, 2010). The key idea of this concept is that there is a limited thermal range of aerobic performance of the species, or a life stage, beyond which the aerobic metabolism is no longer possible. Biochemically these ranges can be detected by the accumulation of end products of anaerobiosis, which is followed by the development of cellular stress and activation of nonspecific cellular stress-response (NCSR) (Kassahn et al., 2009).

Among the NCSR components, high attention was given to the antioxidant enzymes (Almedia et al., 2002), heat shock proteins, such as HSP70 (Triebskorn et al., 2002), lipid and fatty acid composition (Bergé, Barnathan, 2005), lipid peroxidation products (Valavanidis et al., 2006), enzymes and products involved in energy metabolism including anaerobiosis (Almeida et al., 2002), gene expression (Lee et al., 2008), etc.

However, it is unknown whether different populations of the same species vary in activation of NCSR on the edge of their oxygen performance range. In our previous studies we investigated inter-populational differences of energy metabolism during gradual warming in two distant populations of the common Holarctic amphipod Gammarus lacustris Sars, 1863 (Vereshchagina et al., 2016) from freshwater and saline lakes, and NCSR capacity of this species from the freshwater reservoir (Axenov-Gribanov et al., 2016).

The aim of the present study was to investigate the dynamics of HSP70 and lipid peroxidation products along with activity of lactate dehydrogenase, as biomarker of anaerobiosis, 
during gradual temperature increase in Gammarus lacustris from the saline Lake Shira (Republic of Khakassia, Russia).

Heat shock proteins of the HSP70 family protect and restore the structure of cellular proteins under different stresses (Mayer, Goloubinoff, 2017). In many organisms when exposed to stress conditions the amount of HSP70 is elevated due to the increase of damaged proteins (Axenov-Gribanov, 2016; Garbuz, Evgen'ev, 2017). Lactate dehydrogenase catalyzes the reaction of the interconversion of lactate and pyruvate and associated with the processes of carbohydrate and energy metabolism. The enzyme plays an important role in adaptive reactions of the whole organism (Holbrook et al., 1975). Lactate dehydrogenase activity depends on such parameters as intensity of swimming and the availability of their food (Dahlhoff, 2004). There is a wide range of studies in which this parameter was used as an indicator of changes in energy metabolism under stress (Brown-Peterson et al., 2005). Another indicator studied in our work is the level of lipid peroxidation, determined by the dynamics of the content of its products. Peroxide oxidation processes occur in cell lipids (mostly in membrane phospholipids) as a result of the action of reactive oxygen species (ROS) (Guéraud et al., 2010). The processes of peroxidation are series of a chain reactions resulting in a number of products are consistently formed, most of which are toxic (Valavanidis et al., 2006).

G. lacustris is a suitable model to experimentally investigate the impact of different abiotic and biotic stress factors. It has a wide distribution across Northern Hemisphere (Wilhelm, Schindler, 2001). G. lacustris inhabits lentic and lotic ecosystems and has a wide ecological valence (Väinölä, 2007; Takhteev, 2015). Food spectrum of G. lacustris is broad. Being an opportunistic species, in standard conditions it prefers detritus and plant material (Gladyshev et al., 2000). From the previous study, preferable temperature for this species is $15-16{ }^{\circ} \mathrm{C}$ and it is highly tolerant to a wide range of environment $\mathrm{pH}$ variations (6.2-9.2) (Timofeyev, 2010). Also, G. lacustris is highly tolerant to hypoxia, especially in low water temperature. Thereby, this species is a regular inhabitant of eutrophic water bodies. In addition, this species is an indispensable component of many ecosystems. Thereby, G. lacustris is a top predator in food chain in Lake Shira (Republic of Khakassia). Noteworthy, the juvenile representatives predominantly inhabit a depth 1.5-2 $\mathrm{m}$, whereas adult individuals stay apart and live at a depth 5-12 m (Yemelyanova et al., 2002). Due to the fact, that this species is found in most water 
105 bodies of the Holarctic, it can be used as an object of bioindication in assessing the impact of 106 climate change on water bodies and their ecosystems.

107 


\section{Materials and methods}

\section{Sampling site}

G. lacustris were caught in July 2013 with a plankton net at depth of $7 \mathrm{~m}$ from the southern shore of Lake Shira. The temperature recorded at the time of sampling was $15^{\circ} \mathrm{C}$. The lake is located in Southern Siberia $\left(54^{\circ} 29^{\prime} 7.25^{\prime \prime} \mathrm{N}, 90^{\circ} 12^{\prime} 1.49^{\prime \prime} \mathrm{E}\right)$, in the steppe zone of the northern part of the Minusinsk valley (Republic of Khakassia, Russia). Lake Shira is a brackish meromictic water body with a shape of $9.35 \times 5.3 \mathrm{~km}$ and water surface area of $35.9 \mathrm{~km}^{2}$. The maximum depth of the lake reaches $24 \mathrm{~m}$, and the average depth is about $11.2 \mathrm{~m}$ (Degermendzhy et al., 2010; Rogozin et al., 2017). The sampling site represents diverse soils that contain gravel, sand, stone, clay and mud; the sublittoral comprises sand with small stones and gray mud; the black mud prevails in pelagic zone (Yemelyanova et al., 2002).

Lake Shira is one of the most saline water bodies (15-17\%o) inhabited by G. lacustris. Its chemicalc composition corresponds to the following anion-cation ratio (mg/L): $\mathrm{Cl}^{-}-2100, \mathrm{Na}^{+}$$2880, \mathrm{~K}^{+}-37, \mathrm{Mg}^{2+}-1080, \mathrm{CO}_{3}{ }^{2-}-174, \mathrm{Ca}^{2+}-51, \mathrm{SO}_{4}{ }^{2-}-8010, \mathrm{HCO}_{3}{ }^{-}-998$, and environmental pH is close to 8.7 (Kalacheva et al., 2002). In summer, water temperature in the lake littoral zone can reach $28^{\circ} \mathrm{C}$, while the mean annual temperature of water is about $7^{\circ} \mathrm{C}$ (Rogozin et al., 2017).

\section{Experimental design and animal maintenance}

In this study, experiments were carried out during July 2013 at field station of the Institute of Biophysics SB RAS which is located directly at Lake Shira. Animals were selected with approximately the same size of 8-10 mm. According to the study (Zadereev, Gubanov, 2002) this body length can be used to classify adult animals. Immediately after sampling, amphipods were transferred to the laboratory. One hundred individual amphipods were placed into $2 \mathrm{~L}$ glass tanks containing aerated $7{ }^{\circ} \mathrm{C}$ (i.e. the average temperature of the lake) filtered water from their native habitat. Prior to experimental exposure, amphipods were pre-acclimated for 7 days. Tanks with amphipods were kept in a refrigerated showcase (Biryusa, Krasnoyarsk, Russia) to maintain constant temperature during pre-acclimation. Water was exchanged once every 2 days. The experimental animals were fed daily with potatoes ad libitum. Excess food was removed. During acclimation, the amphipods showed high motor activity and no deaths, which can indicate that the acclimation conditions were not stressing for this species. 
Gradual temperature increase experiments were carried out at the rate of $1{ }^{\circ} \mathrm{C}$ per hour by use of a refrigerated bath circulator (CRYO-VT-11, Tomsk, Russia) continuing until 100\%

140

141

142

143

144

145

146

147

148

149

150

151

152

153

154

155

156

157

158

159

160

161

162

163

164

165

166

167

168 mortality occurred (modified from Sokolova and Pörtner (2003)). After every $2{ }^{\circ} \mathrm{C}$ of temperature increase (i.e., every 2 hours) four specimens were randomly collected from each tank, thus, from three to eight replicates were taken at each temperature treatment and shockfrozen in liquid nitrogen. Fixations were conducted upon reaching definite temperatures $-9{ }^{\circ} \mathrm{C}$ (2 h of exposure), $11{ }^{\circ} \mathrm{C}(4 \mathrm{~h}), 13^{\circ} \mathrm{C}(6 \mathrm{~h}), 15^{\circ} \mathrm{C}(8 \mathrm{~h}), 17^{\circ} \mathrm{C}(10 \mathrm{~h}), 19^{\circ} \mathrm{C}(12 \mathrm{~h}), 21{ }^{\circ} \mathrm{C}(14 \mathrm{~h})$, $23{ }^{\circ} \mathrm{C}(16 \mathrm{~h}), 25^{\circ} \mathrm{C}(18 \mathrm{~h}), 27^{\circ} \mathrm{C}(20 \mathrm{~h}), 29^{\circ} \mathrm{C}(22 \mathrm{~h}), 31^{\circ} \mathrm{C}(24 \mathrm{~h})$ and $33^{\circ} \mathrm{C}(26 \mathrm{~h})$.

\section{Biochemical methods}

\section{Assessment of heat shock proteins 70 content}

Total protein was isolated in $0.1 \mathrm{M}$ Tris $\mathrm{HCl}(\mathrm{pH}$ 7.6). The amount of protein in samples was determined using the M. Bradford method (Bradford, 1976) at $595 \mathrm{~nm}$ wavelength. Optical density was measured using the Cary 50 UV/VIS spectrophotometer (Varian, Australia). HSP70 dynamics was determined using standard sodium dodecyl sulfate polyacrylamide gel electrophoresis (SDS-PAGE) in $12.5 \%$ polyacrylamide gel, followed by Western blotting (Laemmli, 1970). For HSP70 visualization, at first, the obtained membranes were incubated with antibodies to HSP70 (monoclonal Anti-Heat Shock Protein 70 antibody produced in mouse; Sigma-Aldrich, \# H5147, 1:1000 dilution). Then, after washing off the unbound antibody, the membranes were incubated in the solution of secondary antibodies conjugated with alkaline phosphatase (Anti-Mouse IgG (whole molecule) - Alkaline Phosphatase antibody produced in goat, Sigma-Aldrich \# A3562, 1:1000 dilution). We used actin as the reference protein. For actin visualization, the following antibodies were used: polyclonal anti- $\alpha$-actin antibodies produced in rabbit (Sigma-Aldrich \#A2668, 1:1000 dilution) and secondary anti-rabbit antibodies (SigmaAldrich \#A9919, 1:1000 dilution). Hsp70 and actin levels were measured by semi-quantitative analysis of grey values on scanned Western blot membranes using ImageJ Package (v.1.41., Wayne Rasband, NIH, USA). The levels of Hsp70 were normalized relative to $\alpha$-actin expression in each sample and given in arbitrary units (arb. un.).

\section{Measurement of lactate dehydrogenase activity}

Activity of lactate dehydrogenase (LDH) was measured using the enzymatic spectrophotometric method. This method is based on the reaction of pyruvate converting into lactate. NADH to $\mathrm{NAD}^{+}$oxidation rate is proportional to the $\mathrm{LDH}$ activity. Measurements were 
169 taken in buffered sodium phosphate solution (0.1 M, pH=7.5) using the LDH-Vital express kit (B

170 23.01, Vital-Development Corporation, Saint-Petersburg, Russian Federation) at $340 \mathrm{~nm}$

171 wavelength and $\mathrm{t}=25^{\circ} \mathrm{C}$ according to the manufacturer's instructions. Optical density was

172 measured using the Cary 50 UV/VIS spectrophotometer (Varian, Australia).

173 Measurement of lipid peroxidation product level

174 The levels of lipid peroxidation products were estimated from monochromatic light flux

175 absorbed by lipid extract in UV spectrum according to the Deryugina et al. modified technique

176 (Deryugina et al., 2010). Frozen specimens were ground in 1:1 heptane-isopropanol extraction

177 mixture. Using the extraction mixture, homogenate volume was brought up to $4.5 \mathrm{ml}$. To

178 separate lipid peroxidase fractions, $1 \mathrm{ml}$ of distilled water was added to samples, which were

179 intensively stirred 10 seconds by hand until fraction became homogeneous then incubated at $18025^{\circ} \mathrm{C}$ for $30 \mathrm{~min}$. After the phase separation, the isopropanol (lower) and heptane (upper)

181 fractions were centrifuged for $2 \mathrm{~min}$ at $14 \mathrm{krpm}$. 97\% ethanol (ratio 1:3) we added to the

182 obtained supernatant, and then the optic density of the solution was measured using the Carry 50

183 Conc UV/VIS spectrophotometer (USA). Diene and triene conjugates, and Schiff bases were 184 measured at wave lengths of 232, 278 and $400 \mathrm{~nm}$, respectively. Content of lipid peroxidation 185 products was estimated in arbitrary units (arb. un.) in terms of isolated double bonds as measured 186 at $220 \mathrm{~nm}$ wavelength.

187

188

189

190

191

192

193

194

195

196

197

\section{Statistical analysis}

All the experiments were carried out with three-eight biological replicates, and biochemical measurements for each sample were performed in triplicate (technical replicates). Immunoblots were analyzed using the ImageJ package (v.1.41., Wayne Rasband, NIH, USA). Normality was checked with the Kolmogorov-Simonov test. Data analysis was performed using the one-way ANOVA test, and the Student-Newman-Keuls test was used as a post hoc-test. When the data distribution deviated from the normal, Kruskal-Wallis with Dunn test as a post hoc-test was used. With p-value $<0.05$, the differences were considered to be significant (to check statistical hypotheses with multiple testing, we also used the Bonferroni correction). Statistical data processing was performed with SigmaPlot package (version 12, Systat Software Inc., USA/Canada). 
198

199

200

201

202

203

204

205

206

207

208

209

210

211

212

213

214

215

216

217

218

219

220

221

222

223

224

225

\section{Results}

In this study, we show that the HSP70 level did not change significantly during the entire exposure to gradual temperature increase from $7{ }^{\circ} \mathrm{C}$ to $33^{\circ} \mathrm{C}$ (Fig. 1).

It is shown that the gradual temperature increase leads to lactate dehydrogenase activity decrease, an important component of anaerobic metabolism (Fig. 2). During the exposure, G. lacustris demonstrated a reliable 16-fold decrease of the enzyme activity from $151.57 \pm 3.80$ $\mathrm{nKat} / \mathrm{mg}$ of protein to $9.19 \pm 3.83 \mathrm{nKat} / \mathrm{mg}$ of protein on reaching $11^{\circ} \mathrm{C}$. Within the range from $11^{\circ} \mathrm{C}$ to $21^{\circ} \mathrm{C}$, the enzyme activity remained low. After that, we observed a short-term reactivation up to $56.37 \pm 21.68 \mathrm{nKat} / \mathrm{mg}$ of protein and $75.97 \pm 27.69 \mathrm{nKat} / \mathrm{mg}$ protein in exposure temperatures of $25^{\circ} \mathrm{C}$ and $27^{\circ} \mathrm{C}$, respectively. However, at the exposure temperatures over $27^{\circ} \mathrm{C}$, the enzyme activity was again lower than the control levels.

To assess the dynamic of oxidation processes under the temperature increase, we measured the content of lipid peroxidation products such as diene conjugates, triene conjugates and Schiff bases. These metabolites reflect various oxidation stages in an organism. Our data shows that in G. lacustris decreased the level of diene conjugates in the neutral lipid fraction (Fig. 3) when temperature reached $21^{\circ} \mathrm{C}(0.24 \pm 0.05)$ and $27^{\circ} \mathrm{C}(0.24 \pm 0.04)$. Changes of diene conjugates content in phospholipid fraction were not observed until the end of the experiment.

It is shown that the gradual temperature increase led to elevated triene conjugates in $G$. lacustris relative to the control level in composition of both phospholipids and neutral lipids (Fig. 4). Elevated levels of triene conjugates were observed in neutral lipids composition, on reaching $31{ }^{\circ} \mathrm{C}$ (two-fold as compared to the basal level, $0.25 \pm 0.03$ ). With phospholipids, the elevation occurred on reaching 31 and $33{ }^{\circ} \mathrm{C}(0.24 \pm 0.03$ and $0.24 \pm 0.02$, respectively).

In analysis of the gradual temperature increase effect on lipid peroxidation end products (Fig. 5) in saltwater G. lacustris, both fractions showed changes in levels of Schiff bases at $31^{\circ} \mathrm{C}$. It should be noted that in case of neutral lipids, the reaction was short-term, while in the phospholipid fraction, content of Schiff bases deviated from the basal level till the end of exposure. 


\section{Discussion}

Various features of the nonspecific cellular stress-response (NCSR) have been outlined here for a saltwater population of $G$. lacustris in order to describe the molecular underpinnings of this species' adaptive potential. This is particularly pertinent, considering that in the near future, it is predicted that this species might be subjected to changing thermal conditions.

The saltwater individuals of $G$. lacustris are more thermoresistant than freshwater individuals of the same species. The time taken for $50 \%$ of individuals held at $30{ }^{\circ} \mathrm{C}$ to reach mortality (LT50) is 15.1 hours less in freshwater specimens than in those from saltwater populations (Vereshchagina et al., 2016). Additionally, the thermal tolerance of these saltwater populations is associated with a lower metabolic cost than in freshwater populations. There is a lower energetic demand associated with sustaining osmotic pressure for G. lacustris individuals in a salt lake, as the water is isoosmotic to the hemolymph of saltwater amphipods. In contrast, the freshwater populations live in a hypoosmotic environment, which is costly on metabolic energy and affects their ability to provide energy for NCSR (Vereshchagina et al., 2016).

The components of NCSR are highly conserved; they are well described in a number of model and non-model organisms (Lushchak, 2011; Elder, Seibel, 2015). Nevertheless, the molecular basis of adaptation, which are caused by the micro-evolution of NCSR regulatory pathways, are still not described. There are some significant NCSR components, such as heat shock proteins (HSPs) and specifically HSP70, which are essential in cellular protection during environmental change. In terms of evolution, HSPs are highly conserved proteins that are found in all organisms from bacteria to humans (Rhee, 2009; Sakharov, 2009; Xie, 2017). As molecular chaperones, HSPs participate in multiple cellular processes including protein folding and transport of proteins through membranes; they also take part in renaturation of cellular proteins that were partially denaturated by proteotoxic stressors (Tomanek, 2010; Shatilina et al., 2011). The participation of HSP70 in response to temperature change has been shown in many organisms, where these proteins function as protectors preventing degradation of cellular proteins (Sørensen et al., 2003; Timofeyev, Steinberg, 2006). However, elevation of the stressinduced HSP70 is energetically demanding; the demanding molecular and biochemical adaptation of the organisms to their temperature niches is often implemented through sustaining the pool of HSP70 proteins in the cells in an amount that is sufficient for protecting cellular proteins from damage under varying abiotic parameters (Bedulina et al., 2013; Garbuz et al, 
257 2017). This is expressed in high constitutively-synthesized levels of HSP70 in cells, and there is

258 no vibrant response to the stress. Basal levels of both constitutive and stress-inducible HSP70

259 forms can vary significantly in different species and in separate populations of the same species

260 when populations are adapted to different environmental conditions. Our previous study showed

261 that in G. lacustris from a freshwater population (Irkutsk region), a significant 9-fold HSP70

262 elevation was observed under gradual temperature change up to $31^{\circ} \mathrm{C}$ (Axenov-Gribanov et al.,

263 2016). It is worth noting that multifold HSP70 accumulations in the freshwater population were

264 observed immediately prior to the critical thermal mortality point of $100 \%$ individuals (Axenov-

265 Gribanov et al., 2016). The results of the current study demonstrate that such multifold

266 elevations of HSP70 levels do not occur in saltwater lake populations of G. lacustris. This

267 indicates that there are key differences in the mechanisms for cellular regulation of stress-

268 induced HSP70 synthesis in different populations of the same species. Revealing the nature of

269 such differences is essential for understanding the molecular basis of the phenotypic plasticity in

270 this species when adapting to various environmental changes.

271 We hypothesize that there are high levels of constitutive HSP70, other molecular

272 chaperones, and other NCSR components in the cells of saltwater animals which may possibly

273 explain the lack of HSP70 accumulation observed here. Our previous study (Vereshchagina et

274 al., 2016) found elevated levels of antioxidant enzyme activity for catalase and glutathione S-

275 transferase in saltwater G. lacustris when compared to the freshwater population. These high

276 levels suggest higher constitutive levels of NCSR in cells; however further research is required to

277 confirm the causes of the observed differences.

278 It is known that in ambient temperature variation, the energy deficiency of cells increases

279 due to a malfunction of the electron transport chain, which forces the organisms to activate less

280 efficient energy recovery pathways, in particularly the anaerobic glycolysis pathway, leading to

281 changes the activity of lactate dehydrogenase (Axenov-Gribanov et al., 2016). During glycolysis,

282 lactate dehydrogenase catalyses in the reversible reaction of the pyruvate-lactate conversion. In

283 the presence of oxygen, pyruvate converts into acetyl coenzyme A and enters the Krebs cycle;

284 however, in anaerobic conditions, or if the mitochondrial electron transport chain is damaged,

285 pyruvate is reversibly converted into lactate (Devlin, 2011). During this study, it was shown that

286 in G. lacustris, the activity of lactate dehydrogenase decreased 16-fold in the first stages of the

287 experiment, when the temperature increased from $7{ }^{\circ} \mathrm{C}$ to $11^{\circ} \mathrm{C}$ (Fig. 2). This decrease in lactate 
288 dehydrogenase activity may have been induced by pyruvate levels increasing during glucose 289 oxygen catabolism. In concentrations over $4 \mathrm{mM}$ (Fregoso-Peñuñuri et al., 2017), pyruvate is 290 capable of inhibiting the enzyme activity in crustaceans. In another study, we demonstrated the 291 elevation of adenosine triphosphate (ATP) and the depletion of glucose content in the first phases 292 of exposure to gradual temperature increase when starting from $13{ }^{\circ} \mathrm{C}$ (Vereshchagina et al., 293 2016). This also denotes the activation of glucose oxygen catabolism. In that same study, at 23 $294{ }^{\circ} \mathrm{C}$, lactate dehydrogenase activity increased up to control levels again, which provided evidence 295 for activation of anaerobic glycolysis processes at these temperatures; though, when $27{ }^{\circ} \mathrm{C}$ is 296 reached, the enzyme activity reduced again and remained low until the end of the experiment. It 297 is worth noting that the multifold accumulation of lactate, as the main marker for anaerobiosis in 298 crustaceans, was observed in this population only when reaching $31{ }^{\circ} \mathrm{C}$. At the same time, the 299 adenosine triphosphate level did not show a significant decrease (Vereshchagina et al., 2016).

In our early studies, the decreased lactate dehydrogenase activity in gradual temperature increase was also observed in $G$. lacustris freshwater population on reaching $17^{\circ} \mathrm{C}$. 302 Nevertheless, we observed a direct correlation between the elevation of lactate and decrease of ATP levels. This indirectly provides support for the theory that anaerobic processes prevail over aerobiosis in the freshwater population, with incomplete deactivation of the aerobic process. Considerable and multiple lactate accumulations in the freshwater population were noted on reaching $29{ }^{\circ} \mathrm{C}$, which was also accompanied with a decrease of lactate dehydrogenase activity (Axenov-Gribanov et al., 2016; Vereshchagina et al., 2016). Thus, the data received in this study supports our early results concerning significant differences in energy metabolism regulation between G. lacustris salt and freshwater populations.

One of the possible causes of shifting energy balance toward anaerobiosis may be the increasing oxidation processes in cells, and the development of oxidative stress (Krone, 1994). The latter often occurs when an accumulation of oxygen actively forms. In this study, oxidative stress is indicated by the change in the levels of lipid peroxidation products - diene (primary products) and triene (secondary products) conjugates, and Schiff bases (end products) in $G$. lacustris (Fig. 3, 4, 5). It is notable that accumulation of the most toxic lipid peroxides (triene conjugates and Schiff bases) in phospholipids occurs at the same time and temperature of exposure as the accumulation of lactate (Vereshchagina et al., 2016). This supports the concept 318 of oxygen-and capacity-limited thermal tolerance (OCLTT) (Pörtner et al., 2017). The concept 
319 deals with molecular mechanisms sustaining oxygen metabolism, which determine the thermal

320 tolerance limits for each species. According to this concept, when environmental parameters

321 deviate from optimal values, organisms switch their metabolism to anaerobiosis. This leads to an

322 accumulation of lactate and other products of anaerobic metabolism (acetate, succinate etc.) in

323 the tissues of animals. Development of cellular stress, changes in the structure and functions of

324 cell membranes, and the activation of lipid peroxidation processes occur at the same time.

325 In our study, in G. lacustris in neutral lipids (heptane fraction), a decreased level of diene

326 conjugates was observed when the temperature reached $21^{\circ} \mathrm{C}$ (Fig. 3). Since no relevant growth

327 was observed in triene conjugate and Schiff base levels, this demonstrates that low-molecular

328 antioxidants are included in antioxidant protection (Kenya et al., 1993; Mittler, 2002).

329

330

331

332

333

334

335

336

337

338

339

340

341

\section{Conclusions}

Gradual temperature increase caused a complex of biochemical reactions in the saltwater G. lacustris studied here, which were expressed by reduced lactate dehydrogenase activity and the activation of lipid peroxidation. There was no multifold increase in HSP70 levels, possibly due to the initially high pool of these proteins in cells, which is energy-efficient for these organisms. The obtained data supports the earlier hypothesis that the increased thermotolerance of $G$. lacustris from the saltwater Lake Shira, as compared to a freshwater lake population of the same species, is caused by the differences in energetic metabolic processes and the energy supply of NCSR mechanisms (Axenov-Gribanov et al., 2016; Vereshchagina et al., 2016). With the development of global climate warming, these reactions could be advantageous for saltwater G. lacustris. Additionally, the studied biochemical reactions can be used as biomarkers for the stress status of aquatic organisms when their habitat temperature changes. 


\section{$342 \quad$ Acknowledgments}

343 We express our gratitude to the team of the Laboratory of Biophysics of Ecosystems at 344 the Institute of Biophysics SB RAS for the accommodation and help during Lake Shira field 345 campaigns. Also, we are indeed grateful to Polina Drozdova, Evgenii Protasov and Molly 346 Czachur for proofreading of the article. 


\section{References}

348 Almeida JA, Diniz YS, Marques SFG, Faine LA, Ribas BO, Burneiko RC, Novelli ELB. 2002.

349 The use of the oxidative stress responses as biomarkers in Nile tilapia (Oreochromis niloticus)

350 exposed to in vivo cadmium contamination. Environment International 27(8):673-679.

351 https://doi.org/10.1016/S0160-4120(01)00127-1

352 Axenov-Gribanov D, Bedulina D, Shatilina Zh, Jakob L, Vereshchagina K, Lubyaga Y, Gurkov

353 A, Shchapova E, Luckenbach T, Lucassen M, Sartoris FJ, Pörtner H-O, Timofeyev M. 2016.

354 Thermal preference ranges correlate with stable signals of universal stress markers in Lake

355 Baikal endemic and Holarctic amphipods. PloS one 11 (10) doi: 10.1371/journal.pone.0164226.

356 Bel'skaya LM. 2016. The state of indices of lipoperoxidation and endogenous intoxication in

357 patients with lung cancer. Bulletin of the Russian Academy of Medical Sciences 71(4).

358 Bradford MM. 1976. A rapid and sensitive method for the quantitation of microgram quantities 359 of protein utilizing the principle of protein-dye binding. Analytical Biochemistry 72:248-254.

360 Brown-Peterson NJ, Larkin P, Denslow N, King C, Manning S, Brouwer M. 2005. Molecular 361 indicators of hypoxia in the blue crab Callinectes sapidus. Marine Ecology Progress Series 286: $362 \quad 203-215$.

363 Callaghan A, Fisher TC, Grosso A, Holloway GJ, Crane M. 2002. Effect of temperature and 364 pirimiphos methyl on biochemical biomarkers in Chironomus riparius Meigen. Ecotoxicology 365 and environmental safety 52(2):128-133. https://doi.org/10.1006/eesa.2002.2160

366 Calow P. 1991. Physiological costs of combating chemical toxicants: ecological implications. 367 Comparative Biochemistry and Physiology Part C: Comparative Pharmacology 100(1-2):3-6.

368 Dahlhoff EP. 2004. Biochemical indicators of stress and metabolism: applications for marine 369 ecological studies. Annu.

Rev.

Physiol. $66: 183-207$.

370 https://doi.org/10.1146/annurev.physiol.66.032102.114509

371 Degermendzhy AG, Zadereev YS, Rogozin DY, Prokopkin IG, Barkhatov YV, Tolomeev A P, 372 Khromechek EB, Janse JP, Mooij WM, Gulati RD. 2010. Vertical stratification of physical, 373 chemical and biological components in two saline lakes Shira and Shunet (South Siberia, 374 Russia). Aquatic Ecology 44(3):619-632. https://doi.org/10.1007/s10452-010-9336-6 
375 Deryugina AV, Koryagin AC, Kopyilova SV, Talamanova MN. 2010. Methods of studying 376 stressful and adaptive reactions of the body in terms of blood system parameters. Nizhny 377 Novgorod: Publishing house of Nizhny Novgorod State University. In Russian

378 Deutsch C, Ferrel A, Seibel B, Pörtner H-O, Huey RB. 2015. Climate change tightens a 379 metabolic constraint on marine habitats. Science 348(6239):1132-1135.

380 Devlin TM. 2011. Textbook of biochemistry. John Wiley \& Sons.

381 Elder LE, Seibel BA. 2015. The thermal stress response to diel vertical migration in the hyperiid 382 amphipod Phronima sedentaria. Comparative Biochemistry and Physiology Part A: Molecular 383 \& Integrative Physiology 187:20-26. https://doi.org/10.1016/j.cbpa.2015.04.008

384 Fregoso-Peñuñuri AA, Valenzuela-Soto EM, Figueroa-Soto CG, Peregrino-Uriarte AB, Ochoa385 Valdez M, Leyva-Carrillo L, Yepiz-Plascencia G. 2017. White shrimp Litopenaeus vannamei 386 recombinant lactate dehydrogenase: Biochemical and kinetic characterization. Protein 387 expression and purification 137:20-25. https://doi.org/10.1016/j.pep.2017.06.010

388 Freire CA, Welker AF, Storey JM, Storey KB, Hermes-Lima M. 2011. Oxidative stress in 389 estuarine and intertidal environments (temperate and tropical). Oxidative stress in aquatic 390 ecosystems 41-57. doi: 10.1002/9781444345988.ch3

391 Garbuz, DG, Evgen'ev MB. 2017. The evolution of heat shock genes and expression patterns of 392 heat shock proteins in the species from temperature contrasting habitats. Russian Journal of 393 Genetics 53(1):21-38. https://doi.org/10.1134/S1022795417010069

394 Gladyshev MI, Emelianova AY, Kalachova GS, Zotina TA, Gaevsky NA, Zhilenkov MD. 2000. 395 Gut content analysis of Gammarus lacustris from a Siberian lake using biochemical and 396 biophysical methods. Hydrobiologia 431(2):155-163. https://doi.org/10.1023/A:1004036111433

397 Holbrook JJ, Liljas A, Steindel SJ, Rossmann MG. 1975. 4 Lactate Dehydrogenase. In The 398 enzymes. Academic Press.11:191-292. https://doi.org/10.1016/S1874-6047(08)60212-7

399 Huey RB, Buckley LB, Du W. 2018. Biological buffers and the impacts of climate 400 change. Integrative zoology. doi: 10.1111/1749-4877.12321. 
401 Iacarella JC, Dick JT, Alexander ME, Ricciardi A. 2015. Ecological impacts of invasive alien 402 species along temperature gradients: testing the role of environmental matching. Ecological 403 applications 25(3):706-716. https://doi.org/10.1890/14-0545.1

404 Intergovernmental Panel on Climate Change. Climate Change 2014-Impacts, Adaptation and 405 Vulnerability: Regional Aspects. 2014. Cambridge University Press 1-6.

406 Kalacheva GS, Gubanov VG, Gribovskaya IV, Gladchenko IA, Zinenko GK, Savitsky SV. 2002. 407 Chemical analysis of Lake Shira water (1997-2000). Aquatic ecology 36(2):123-141. 408 https://doi.org/10.1023/A:1015695813280

409 Kassahn KS, Crozier RH, Pörtner HO, Caley MJ. 2009. Animal performance and stress: 410 responses and tolerance limits at different levels of biological organisation. Biological Reviews 411 84(2):277-292. https://doi.org/10.1111/j.1469-185X.2008.00073.x

412 Keniya MV, Lukash AI, Gus'kov EP. 1993. The role of low-molecular antioxidants in oxidative 413 stress. Progress in modern biology 4:456-470.Keniya MV, Lukash AI, Gus'kov EP. 1993. The 414 role of low-molecular antioxidants in oxidative stress. Progress in modern biology 4:456-470. In 415 Russian

416 Laemmli U. Cleavage of structural proteins during the assembly of the head of bacteriophage. 417 1970. Nature 227:680-685. doi:10.1038/227680a0

418 Larade K, Storey KB. 2002. A Profile of the Metabolic Responses to Anoxia in Marine. Sensing, 419 Signaling and Cell Adaptation 3:27.

420 Le Pennec G, Le Pennec M. 2003. Induction of glutathione-S-transferases in primary cultured 421 digestive gland acini from the mollusk bivalve Pecten maximus (L.): application of a new 422 cellular model in biomonitoring studies. Aquatic toxicology 64(2):131-142. 423 https://doi.org/10.1016/S0166-445X(03)00041-9

424 Lee KW, Raisuddin S, Rhee JS, Hwang DS, Yu IT, Lee YM, Lee JS. 2008. Expression of 425 glutathione S-transferase (GST) genes in the marine copepod Tigriopus japonicus exposed to 426 trace metals. Aquatic Toxicology 89(3):158-166. https://doi.org/10.1016/j.aquatox.2008.06.011

427 Lushchak VI. 2011. Environmentally induced oxidative stress in aquatic animals. Aquatic 428 toxicology 101:13-30. doi: 10.1016/j.aquatox.2010.10.006 
429 Mansilla MC, Mendoza D. 2017. Regulation of membrane lipid homeostasis in bacteria upon 430 temperature changes. Biogenesis of fatty acids, lipids and membranes. Springer 431 http://doi.org.10.1007/978-3-319-43676-0_56-2.

432 Mayer MP, Goloubinoff P. 2017. The HSP70 Molecular Chaperone Machines. Lausanne: 433 Frontiers Media. doi: 10.3389/978-2-88945-125-8

434 Mittler R. 2002. Oxidative stress, antioxidants and stress tolerance. Trends in plant science 435 7(9):405 - 410. https://doi.org/10.1016/S1360-1385(02)02312-9

436 Newell RC. 2013. Adaptation to environment: essays on the physiology of marine animals. 437 Elsevier 554.

438 O’Reilly CM, Sharma S, Gray DK, Hampton SE, Read JS, Rowley RJ, Schneider P, Lenters JD, 439 McIntyre PB, Kraemer BM, Weyhenmeyer GA, Straile D, Dong B, Adrian R, Allan MG, 440 Anneville O, Arvola L, Austin J, Bailey JL, Baron JS, Brookes JD, de Eyto E, Dokulil MT, 441 Hamilton DP, Havens K, Hetherington AL, Higgins SN, Hook S, Izmest'eva LR, Joehnk KD, 442 Kangur K, Kasprzak P, Kumagai M, Kuusisto E, Leshkevich G, Livingstone DM, MacIntyre S, 443 May L, Melack JM, Mueller-Navarra DC, Naumenko M, Noges P, Noges T, North RP., Plisnier 444 P-D, Rigosi A, Rimmer A, Rogora M, Rudstam LG, Rusak JA, Salmaso N, Samal NR, Schindler 445 DE, Schladow SG, Schmid M, Schmidt SR, Silow E, Soylu ME, Teubner K, Verburg P, 446 Voutilainen A, Watkinson A, Williamson CE, Zhang G. 2015. Rapid and highly variable 447 warming of lake surface waters around the globe: GLOBAL LAKE SURFACE WARMING. 448 Geophysical Research Letters 42(10):773-781. DOI: 10.1002/2015GL066235

449 Pethybridge HR, Parrish CC, Morrongiello J, Young JW, Farley JH, Gunasekera RM, Nichols 450 PD. 2015. Spatial patterns and temperature predictions of tuna fatty acids: tracing essential 451 nutrients and changes in primary producers. PloS one 10(7) 452 https://doi.org/10.1371/journal.pone.0131598.

453 Philp A, Macdonald AL, Watt PW. 2005. Lactate-a signal coordinating cell and systemic 454 function. Journal of Experimental Biology 208(24):4561-4575. doi: 10.1242/jeb.01961

455 Podrabsky JE, Stillman JH, Tomanek L. 2015. Biochemical adaptation: unity in principles, 456 diversity in solutions. Journal of Experimental Biology 218:1797-1798. 
457 Pörtner HO, Bock C, Mark FC. 2017. Oxygen-and capacity-limited thermal tolerance: bridging 458 ecology and physiology. Journal of Experimental Biology 220(15):2685-2696. doi: $45910.1242 /$ jeb. 134585

460 Pörtner HO, Farrell, AP, Knust R, Lannig G, Mark FC, Storch D. 2009. Adapting to climate 461 change-response. Science 323, 876-877.

462 Pörtner HO, Knust R. 2007. Climate change affects marine fishes through the oxygen limitation 463 of thermal tolerance. Science 315(5808):95-97. doi: 10.1126/science.1135471

464 Pörtner HO. 2008. Ecosystem effects of ocean acidification in times of ocean warming: a 465 physiologist's view. Marine Ecology Progress Series 373:203-217. doi: 10.3354/meps07768

466 Pörtner HO. 2010. Oxygen-and capacity-limitation of thermal tolerance: a matrix for integrating 467 climate-related stressor effects in marine ecosystems. Journal of Experimental Biology 468 213(6):881-893. doi: 10.1242/jeb.037523

469 Rhee JS, Raisuddin S, Lee KW, Seo JS, Ki JS, Kim IC, Lee JS. 2009. Heat shock protein (Hsp) 470 gene responses of the intertidal copepod Tigriopus japonicus to environmental toxicants. 471 Comparative Biochemistry and Physiology Part C: Toxicology \& Pharmacology 149(1):104472 112. https://doi.org/10.1016/j.cbpc.2008.07.009

473 Rogozin D, Zadereev E, Prokopkin I, Tolomeev A, Barkhatov Y, Khromechek E, Degermendzhi 474 N, Drobotov A, Degermendzhi A. 2017. Comparative Study of the Stability of Stratification and 475 the Food Web Structure in the Meromictic Lakes Shira and Shunet (South Siberia, Russia). 476 Ecology of Meromictic Lakes 228:89-124. https://doi.org/10.1007/978-3-319-49143-1_5.

477 Rogozin DY, Tarnovsky MO, Belolipetski VM, Zykov VV, Zadereev ES, Tolomeev AP, 478 Drobotov AV, Barkhatov YV, Gaevsky NA, Gorbaneva TB, Kolmakova AA, Degermendzhi 479 AG. Disturbance of meromixis in saline Lake Shira (Siberia, Russia): Possible reasons and 480 ecosystem response. Limnologica http://dx.doi.org/10.1016/j.limno.2017.06.004

481 Sakharov DA, Stepanov AV, Shkurnikov MY, Tonevitskii AG. 2009. Short-term highly intense 482 physiological stress causes an increase in the expression of heat shock protein in human 483 leukocytes. Bulletin of experimental biology and medicine 147(3):361-365. 484 https://doi.org/10.1007/s10517-009-0509-z 
485 Sars GO. 1863. Om en i Sommeren 1862 foretagen zoologisk Reise i Christianias og Trondhjems 486 Stifter. Dahl.

487 Shatilina ZM, Riss WH, Protopopova MV, Trippe M, Meyer EI, Pavlichenko VV, Bedulina DS, 488 Axenov-Gribanov DV, Timofeyev MA. 2011. The role of the heat shock proteins (HSP70 and 489 sHSP) in the thermotolerance of freshwater amphipods from contrasting habitats. Journal of 490 Thermal Biology 36(2):142-149. https://doi.org/10.1016/j.jtherbio.2010.12.008

491 Shchapova EP, Axenov-Gribanov DV, Lubyaga YA, Shatilina ZM, Vereshchagina KP, Protasov 492 ES, Madyarova EV, Timofeyev MA. 2018. Crude oil at concentrations considered safe promotes 493 rapid stress-response in Lake Baikal endemic amphipods. Hydrobiologia 805(1):189-201. 494 https://doi.org/10.1007/s10750-017-3303-3

495 Sokolova IM, Pörtner HO. 2003. Metabolic plasticity and critical temperatures for aerobic scope 496 in a eurythermal marine invertebrate (Littorina saxatilis, Gastropoda: Littorinidae) from different 497 latitudes. Journal of Experimental Biology 206(1):195-207. doi: 10.1242/jeb.00054

498 Sørensen JG, Kristensen TN, Loeschcke V. 2003. The evolutionary and ecological role of heat 499 shock proteins. Ecology Letters 6(11):1025-1037. doi: 10.1046/j.1461-0248.2003.00528.x

500 Stillman JH, Somero GN. 2001. A comparative analysis of the evolutionary patterning and 501 mechanistic bases of lactate dehydrogenase thermal stability in porcelain crabs, genus 502 Petrolisthes. Journal of Experimental Biology 204:767-776.

503 Takhteev VV, Berezina NA, Sidorov DA. 2015. Checklist of the Amphipoda (Crustacea) from 504 continental waters of Russia, with data on alien species. Arthropoda Selecta 24(3):335-370.

505 Timofeyev MA, Steinberg CEW. 2006. Antioxidant response to natural organic matter (NOM) 506 exposure in three Baikalean amphipod species from contrasting habitats. Comparative 507 Biochemistry and Physiology - Part B: Biochemistry \& Molecular Biology 145:197-203. doi: $508 \quad 10.1016 /$ j.cbpb.2006.07.004

509 Timofeyev MA. 2010. Ecological and physiological aspects of adaptation to environmental 510 factors in endemic Baikal and palearctic amphipods. Doctoral thesis, Tomsk Stat Univ. In 511 Russian 
512 Timoshkin OA, Sitnikova TY, Pronin NM, Proviz VI, Melnik NG, Kamaltynov RM, Mazepova

513 DF, Shoshnin AV. 2001. Index of animal species inhabiting Lake Baikal and its catchment area.

514 Nauka, Novosibirsk 1:74-113.

515 Tomanek L. 2010. Variation in the heat shock response and its implication for predicting the 516 effect of global climate change on species' biogeographical distribution ranges and metabolic 517 costs. Journal of Experimental Biology 213:971-979. doi: 10.1242/jeb.038034

518 Triebskorn R, Adam S, Casper H, Honnen W, Pawert M, Schramm M, Schwaiger J, Köhler H.519 R. 2002. Biomarkers as diagnostic tools for evaluating effects of unknown past water quality 520 conditions on stream $\quad$ organisms. Ecotoxicology 11:451-465. 521 https://doi.org/10.1023/A:1021009418421

522 Tu HT, Silvestre F, De Meulder B, Thome JP, Phuong NT, Kestemont P. 2012. Combined 523 effects of deltamethrin, temperature and salinity on oxidative stress biomarkers and 524 acetylcholinesterase activity in the black tiger shrimp (Penaeus monodon). Chemosphere 525 86(1):83-91. https://doi.org/10.1016/j.chemosphere.2011.09.022

526 Väinölä R, Witt JDS, Grabowski M, Bradbury JH, Jazdzewski K, Sket B. 2007. Global diversity 527 of amphipods (Amphipoda; Crustacea) in freshwater. Hydrobiologia 595:241-255. 528 https://doi.org/10.1007/s10750-007-9020-6

529 Van Straalen NM, Hoffmann AA. 2000. Review of experimental evidence for physiological 530 costs of tolerance to toxicants. Demography in Ecotoxicology 147-161.

531 Verbitsky VB, Verbitskaya TI, Malysheva OA. 2014. Temperature behavior of the cladoceran 532 Simocephalus vetulus O.F. Müller, 1776 (Crustacea, Cladocera) from the Rybinsk water 533 reservoir. Doklady Biological Sciences 455:91-93. https://doi.org/10.1134/S0012496614020069

534 Vereshchagina KP, Lubyaga YA, Shatilina Z, Bedulina D, Gurkov A, Axenov-Gribanov DV, 535 Baduev B, Kondrateva ES, Gubanov M, Zadereev E, Sokolova I, Timofeyev M. 2016. Salinity 536 modulates thermotolerance, energy metabolism and stress response in amphipods Gammarus 537 lacustris. PeerJ https://doi.org/10.7717/peerj.2657. 
538 Wilhelm FM, Schindler DW. 2000. Reproductive strategies of Gammarus lacustris (Crustacea: 539 Amphipoda) along an elevation gradient. Functional Ecology 14(4):413-422. 540 https://doi.org/10.1046/j.1365-2435.2000.00426.x

541 XieY. 2017. Molecular characterization of the HSP70 and HSP90 genes in Asian clam 542 (Corbicula fluminea) and their expression analysis during heavy metal exposure. Gene Reports 543 7:18-24. https://doi.org/10.1016/j.genrep.2017.01.002

544 Zadereev ES, Tolomeyev AP, Drobotov AV, Emeliyanova AY, Gubanov MV. 2010. The 545 vertical distribution and abundance of Gammarus lacustris in the pelagic zone of the meromictic 546 lakes Shira and Shunet (Khakassia, Russia). Aquatic ecology 44(3):531-539. 547 https://doi.org/10.1007/s10452-010-9329-5

548 Zadereev YS, Gubanov V. 2002. The effect of chemicals released by Gammarus lacustris on the 549 depth distribution of Arctodiaptomus salinus in laboratory conditions. Aquatic Ecology 550 36(2):257-260. https://doi.org/10.1023/A:1015635903281

551

552 
Figure 1

HSP70 levels in Lake Shira G. lacustris amphipods during exposure to gradual temperature increase $\left(1^{\circ} \mathrm{C} / \mathrm{h}\right)$.

HSP70 levels presented in arbitrary units. Columns highlighted by red outline indicate the control level. Data are presented as means \pm standard deviation of the mean. Ind. - indicates number of individuals of amphipods. Number of replicates: $n, 7^{\circ} \mathrm{C}=3$ (12 ind.); $n, 9^{\circ} \mathrm{C}=5$ (20 ind.); $n, 11^{\circ} \mathrm{C}=4$ (16 ind.); $n, 13^{\circ} \mathrm{C}=3$ (12 ind.); $n, 15^{\circ} \mathrm{C}=4$ (16 ind.); $n, 17^{\circ} \mathrm{C}=5$ (20 ind.); $n$, $19^{\circ} \mathrm{C}=4$ (16 ind.); $n, 21^{\circ} \mathrm{C}=5$ (20 ind.); $n, 23^{\circ} \mathrm{C}=4$ (16 ind.); $n, 25^{\circ} \mathrm{C}=4\left(16\right.$ ind.); $n, 27^{\circ} \mathrm{C}=$ 4 (16 ind.); $n, 29^{\circ} \mathrm{C}=4$ (16 ind.); $n, 31^{\circ} \mathrm{C}=5$ (20 ind.); $\mathrm{n}, 33^{\circ} \mathrm{C}=4$ (16 ind.).

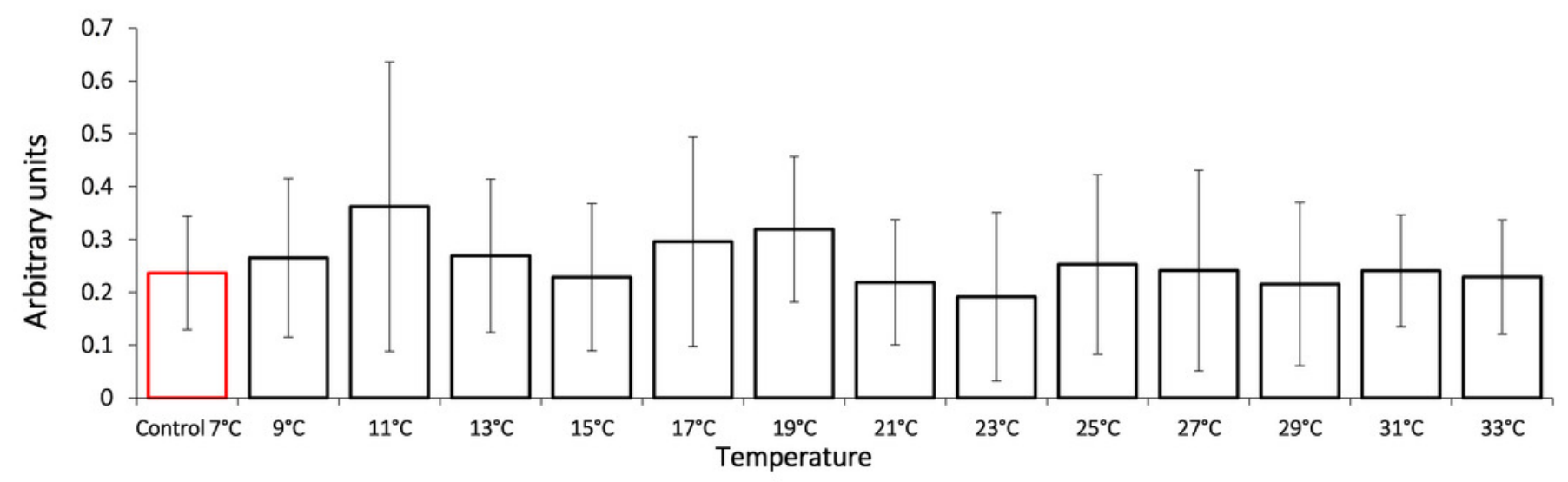


Figure 2

Lactate dehydrogenase activity (in nKat/mg of protein) in Lake Shira G. lacustris amphipods during exposure to gradual temperature increase $\left(1^{\circ} \mathrm{C} / \mathrm{h}\right)$.

Columns highlighted by red outline indicate the control level. Asterisks $(*)$ denotes a significant difference $(p<0.05)$ from the control $7^{\circ} \mathrm{C}$. Data are presented as means \pm standard deviation of the mean. Ind. - indicates number of individuals of amphipods. Number of replicates: $n, 7^{\circ} \mathrm{C}=3$ (12 ind.); $n, 9^{\circ} \mathrm{C}=5$ (20 ind.); $n, 11^{\circ} \mathrm{C}=3$ (12 ind.); $n, 13^{\circ} \mathrm{C}=3$ (12 ind.); $n, 15^{\circ} \mathrm{C}=4$ (16 ind.); $n, 17^{\circ} \mathrm{C}=4$ (16 ind.); $n, 19^{\circ} \mathrm{C}=4$ (16 ind.); $n, 21^{\circ} \mathrm{C}=3$ (12 ind.); $n$, $23^{\circ} \mathrm{C}=4$ (16 ind.); $n, 25^{\circ} \mathrm{C}=3$ (12 ind.); $n, 27^{\circ} \mathrm{C}=4(16$ ind. $) ; n, 29^{\circ} \mathrm{C}=3$ (12 ind.); $n, 31^{\circ} \mathrm{C}=$ 3 (12 ind.); $n, 33^{\circ} \mathrm{C}=4$ (16 ind.).

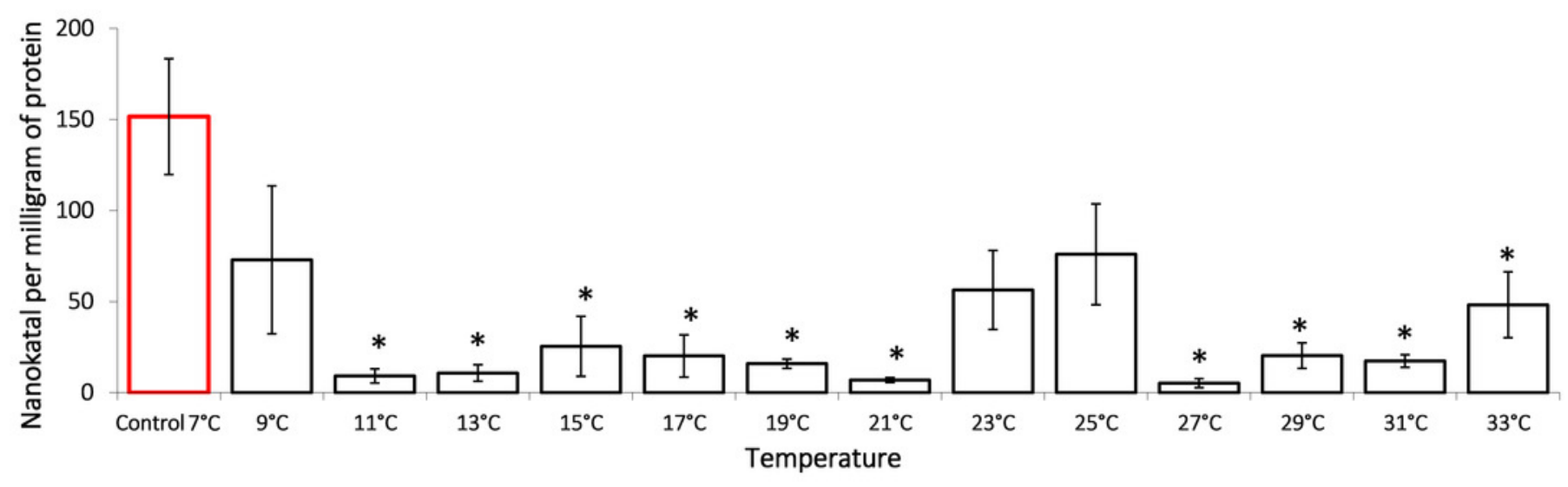




\section{Figure 3}

Levels of diene conjugates in neutral lipids (heptane fraction) and phospholipids (isopropanol fraction) in Lake Shira G. lacustris amphipods during exposure to gradual temperature increase $\left(1^{\circ} \mathrm{C} / \mathrm{h}\right)$.

Diene conjugate levels presented in arbitrary units. Columns highlighted by red outline indicate the control level. Asterisks $(*)$ denotes a significant difference $(p<0.05)$ from the control $7^{\circ} \mathrm{C}$. Data are presented as means \pm standard deviation of the mean. Ind. - indicates number of individuals of amphipods. Number of replicates (neutral lipids): $n, 7^{\circ} \mathrm{C}=7$ (28 ind.); $\mathrm{n}, 9^{\circ} \mathrm{C}=5(20$ ind. $) ; n, 11^{\circ} \mathrm{C}=6(24$ ind. $) ; n, 13^{\circ} \mathrm{C}=6(24$ ind. $) ; n, 15^{\circ} \mathrm{C}=7$ (28 ind. $) ; n, 17^{\circ} \mathrm{C}=$ $7\left(28\right.$ ind.); $n, 19^{\circ} \mathrm{C}=6$ (24 ind.); $n, 21^{\circ} \mathrm{C}=6$ (24 ind.); $n, 23^{\circ} \mathrm{C}=7$ (28 ind.); $n, 25^{\circ} \mathrm{C}=5(20$ ind.); $n, 27^{\circ} \mathrm{C}=6$ (24 ind.); $n, 29^{\circ} \mathrm{C}=7$ (28 ind.); $n, 31^{\circ} \mathrm{C}=7$ (28 ind.); $n, 33^{\circ} \mathrm{C}=6$ (24 ind.). Number of replicates (phospholipids): $n, 7^{\circ} \mathrm{C}=8$ (32 ind.), $n, 9^{\circ} \mathrm{C}=7$ (28 ind.); $n, 11^{\circ} \mathrm{C}=6(24$ ind.); $n, 13^{\circ} \mathrm{C}=6\left(24\right.$ ind.); $n, 15^{\circ} \mathrm{C}=7$ (28 ind.); $n, 17^{\circ} \mathrm{C}=6$ (24 ind.); $n, 19^{\circ} \mathrm{C}=6$ (24 ind.); $n$, $21^{\circ} \mathrm{C}=7$ (28 ind.); $n, 23^{\circ} \mathrm{C}=7$ (28 ind.); $n, 25^{\circ} \mathrm{C}=6$ (24 ind.); $n, 27^{\circ} \mathrm{C}=6$ (24 ind.); $n, 29^{\circ} \mathrm{C}=$ 7 (28 ind.); $n, 31^{\circ} \mathrm{C}=7$ (28 ind.); $n, 33^{\circ} \mathrm{C}=6$ (24 ind.).

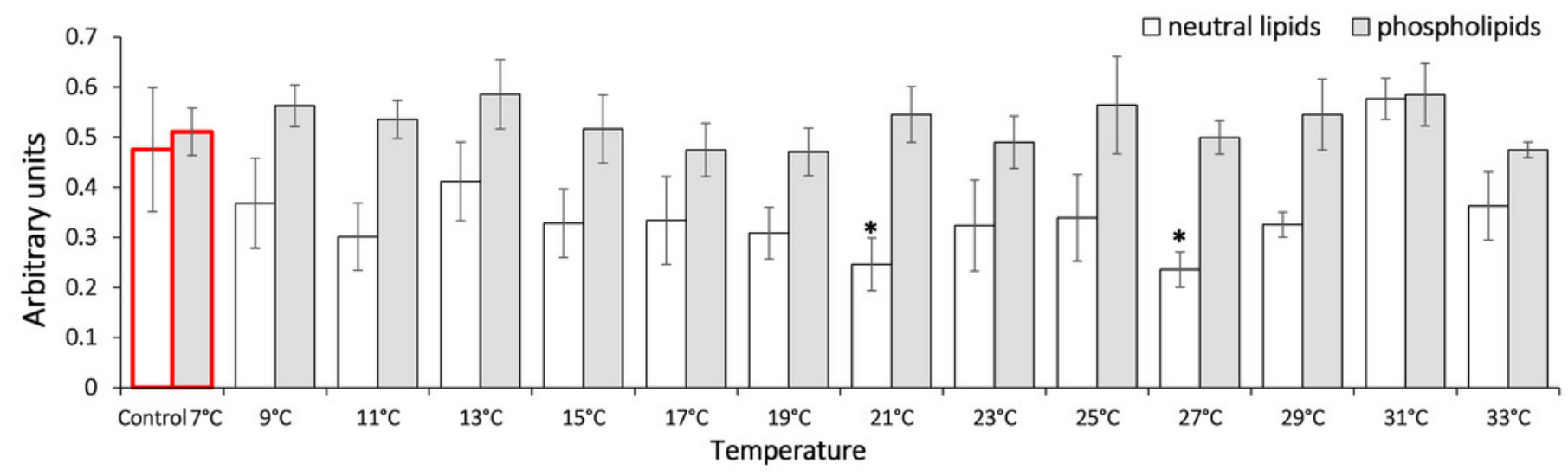




\section{Figure 4}

Levels of triene conjugates in neutral lipids (heptane fraction) and phospholipids (isopropanol fraction) in Lake Shira G. lacustris amphipods during exposure to gradual temperature increase $\left(1^{\circ} \mathrm{C} / \mathrm{h}\right)$.

Triene conjugate levels presented in arbitrary units. Columns highlighted by red outline indicate the control level. Asterisks $(*)$ denotes a significant difference $(p<0.05)$ from the control $7^{\circ} \mathrm{C}$. Data are presented as means \pm standard deviation of the mean. Ind. - indicates number of individuals of amphipods. Number of replicates (neutral lipids): $n, 7^{\circ} \mathrm{C}=5$ (20 ind.); $\mathrm{n}, 9^{\circ} \mathrm{C}=5(20$ ind. $) ; n, 11^{\circ} \mathrm{C}=7(28$ ind. $) ; n, 13^{\circ} \mathrm{C}=6(24$ ind. $) ; n, 15^{\circ} \mathrm{C}=7$ (28 ind. $) ; n, 17^{\circ} \mathrm{C}=$ 6 (24 ind.); $n, 19^{\circ} \mathrm{C}=7$ (28 ind.); $n, 21^{\circ} \mathrm{C}=6$ (24 ind.); $n, 23^{\circ} \mathrm{C}=7$ (28 ind.); $n, 25^{\circ} \mathrm{C}=5$ (20 ind.); $n, 27^{\circ} \mathrm{C}=7$ (28 ind.); $n, 29^{\circ} \mathrm{C}=6$ (24 ind.); $n, 31^{\circ} \mathrm{C}=7$ (28 ind.); $n, 33^{\circ} \mathrm{C}=6$ (24 ind.). Number of replicates (phospholipids): $n, 7^{\circ} \mathrm{C}=8$ (32 ind.); $n, 9^{\circ} \mathrm{C}=7$ (28 ind.); $n, 11^{\circ} \mathrm{C}=7(28$ ind.); $n, 13^{\circ} \mathrm{C}=6$ (24 ind.); $n, 15^{\circ} \mathrm{C}=7$ (28 ind.); $n, 17^{\circ} \mathrm{C}=7$ (28 ind.); $n, 19^{\circ} \mathrm{C}=6$ (24 ind.); $n$, $21^{\circ} \mathrm{C}=7$ (28 ind.); $n, 23^{\circ} \mathrm{C}=7$ (28 ind.); $n, 25^{\circ} \mathrm{C}=6(24$ ind. $) ; n, 27^{\circ} \mathrm{C}=6$ (24 ind.); $n, 29^{\circ} \mathrm{C}=$ 7 (28 ind.); $n, 31{ }^{\circ} \mathrm{C}=7$ (28 ind.); $n, 33{ }^{\circ} \mathrm{C}=6$ (24 ind.).

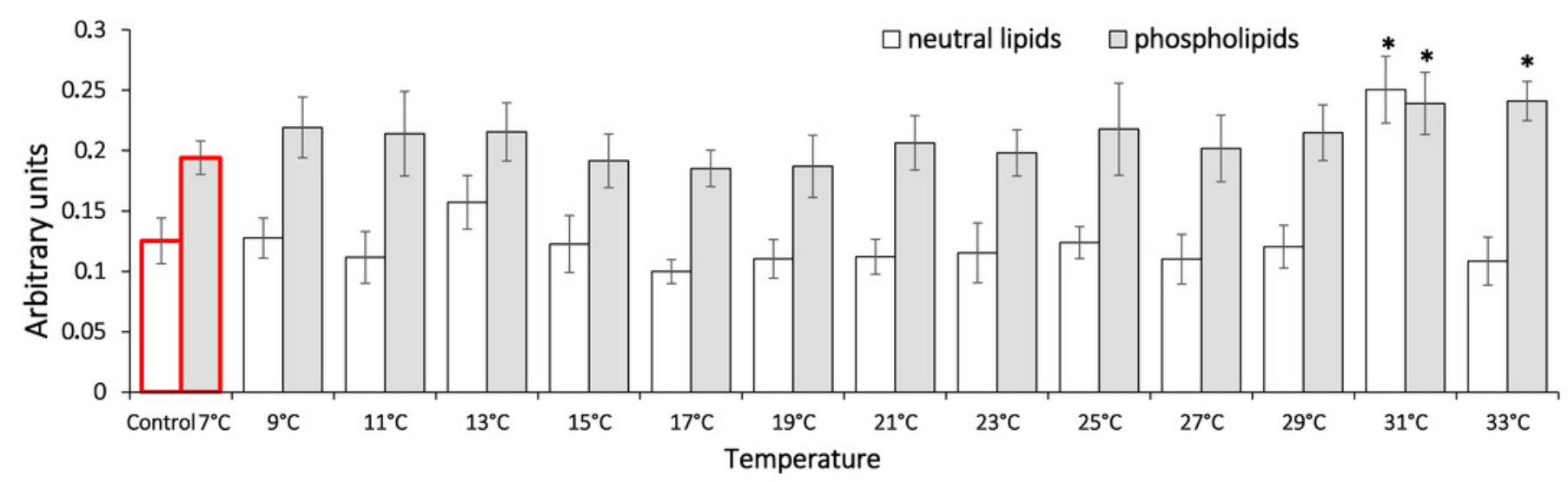




\section{Figure 5}

Levels of Schiff's bases in neutral lipids (heptane fraction) and phospholipids (isopropanol fraction) in Lake Shira G. lacustris amphipods during exposure to gradual temperature increase $\left(1^{\circ} \mathrm{C} / \mathrm{h}\right)$.

Schiff's base levels presented in arbitrary units. Columns highlighted by red outline indicate the control level. Asterisks $(*)$ denotes a significant difference $(p<0.05)$ from the control $7^{\circ} \mathrm{C}$. Data are presented as means \pm standard deviation of the mean. Ind. - indicates number of individuals of amphipods. Number of replicates (neutral lipids): $n, 7^{\circ} \mathrm{C}=7$ (28 ind.); $n, 9^{\circ} \mathrm{C}=6$ (24 ind.); $n, 11^{\circ} \mathrm{C}=6$ (24 ind.); $n, 13^{\circ} \mathrm{C}=5$ (20 ind.); $n, 15^{\circ} \mathrm{C}=7$ (28 ind.); $n, 17^{\circ} \mathrm{C}=6(24$ ind.); $n, 19^{\circ} \mathrm{C}=7$ (28 ind.); $n, 21^{\circ} \mathrm{C}=6$ (24 ind.); $n, 23^{\circ} \mathrm{C}=7$ (28 ind.); $n, 25^{\circ} \mathrm{C}=6$ (24 ind.); $n$, $27^{\circ} \mathrm{C}=7$ (28 ind.); $n, 29^{\circ} \mathrm{C}=5$ (20 ind.); $n, 31^{\circ} \mathrm{C}=7$ (28 ind.); $n, 33^{\circ} \mathrm{C}=6$ (24 ind.). Number of replicates (phospholipids): $n, 7^{\circ} \mathrm{C}=8$ (32 ind.); $n, 9^{\circ} \mathrm{C}=7$ (28 ind.); $n, 11^{\circ} \mathrm{C}=6$ (24 ind.); $n$, $13^{\circ} \mathrm{C}=6(24$ ind. $) ; n, 15^{\circ} \mathrm{C}=7$ (28 ind.) $n, 17^{\circ} \mathrm{C}=7$ (28 ind. $) ; n, 19^{\circ} \mathrm{C}=6$ (24 ind. $) ; n, 21^{\circ} \mathrm{C}=$ 7 (28 ind.); $n, 23^{\circ} \mathrm{C}=7$ (28 ind.); $n, 25^{\circ} \mathrm{C}=6$ (24 ind.); $n, 27^{\circ} \mathrm{C}=7$ (28 ind.); $n, 29^{\circ} \mathrm{C}=7$ (28 ind.); $n, 31{ }^{\circ} \mathrm{C}=6$ (24 ind.); $n, 33^{\circ} \mathrm{C}=6$ (24 ind.).

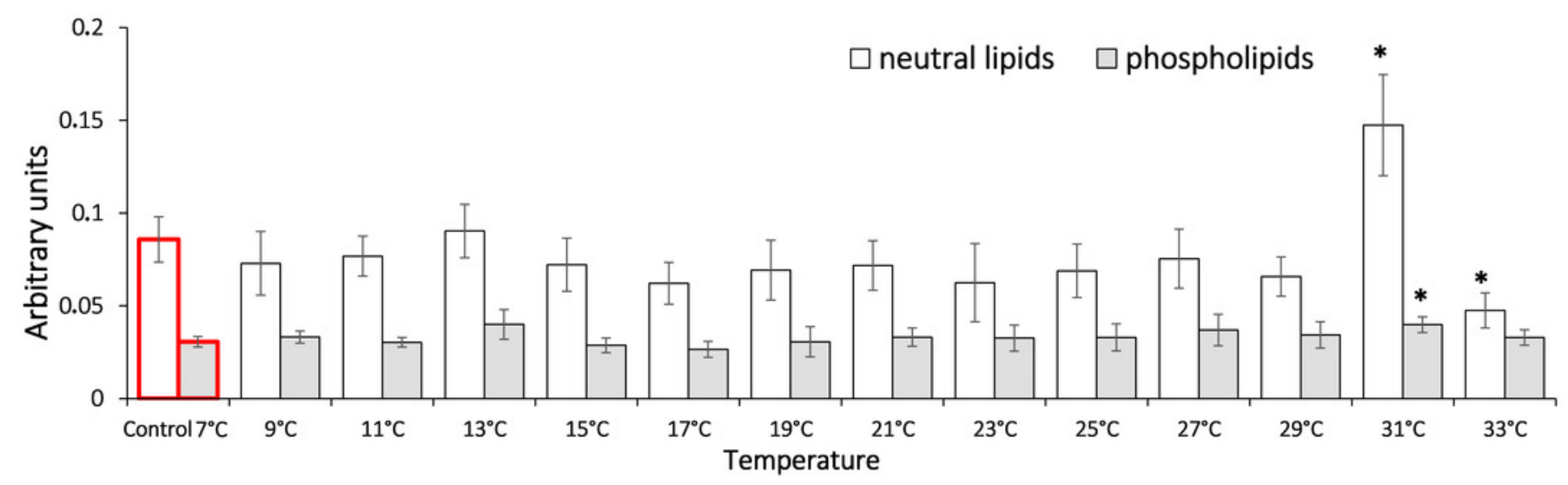

